\title{
Teachers' Perceptions about Readability and Modification of Authentic Texts Chosen for Teaching Reading in the Vietnamese Context
}

Nguyen Duy Khang

\begin{abstract}
The article presents EFL teachers' perceptions towards the readability of authentic texts and the ways of modifying authentic materials used in teaching reading. Essential tools to check the ease of understanding authentic texts are also suggested. The data was collected by means of a questionnaire and test. The findings show that awareness of readability and modification of authentic texts in teaching reading benefited both the teachers in facilitating their teaching process and the learners in their language acquisition.
\end{abstract}

Key words: reading, readability, text readability, authenticity, text modification, language acquisition

\section{Introduction}

In recent years, teaching English as a foreign language has paid much attention to providing learners with appropriate input to improve the efficiency of language acquisition. In Vietnam, reading is one of the most important skills for students of English, because English is not spoken in social situations. Since input from reading materials contributes to learners' language acquisition, teachers need to be aware of the significance of authentic texts in helping learners to comprehend and acquire the language naturally. To take full advantages of authentic materials, their readability and possible modification need to be considered.

\section{Background and Literature Review}

In Vietnam, using authentic materials in teaching reading is not necessarily well known to EFL teachers. Although a wide range of authentic teaching materials have been adopted in educational programmes, they have not always been given the attention they deserve. Besides employing the reading texts available in the course books, teachers collect texts from sources such as the Internet, magazines, and book for use in teaching and testing. They do not always consider whether the texts are readable or suitable for their learners. This lack of consideration indicates that while teachers understand the important role of authentic texts they may be unaware of the role of readability and the possibility of text modification for improved outcomes. The reality of the investigated context shows that many students struggle with reading comprehension, often receiving low marks. To address text readability and modification, the author of the paper focuses on answering the following questions:

- Do teachers pay attention to readability and modification when using authentic texts for teaching reading?

- Does text modification enhance the text readability?

The three main points of authentic text, text readability, text modification have been reviewed for a theoretical background of the paper that follows. 
First, the term authentic text has been defined and discussed in numerous studies (Wilkins, 1976; Little et al., 1988; Crytal, 1997; Guariento \& Morley, 2001; Ur,2008). An authentic text, as defined by Little et al. (1988) is "created to fulfill language community in which it was produced" (p. 27). This viewpoint is strengthened by Wilkins' (1976) findings on the use of authentic text in classroom. He states that authentic language helps learners to bridge the gap between theory and practice. Learners are provided with "real" language which is written or spoken by native speakers. They can, therefore, apply it to practical situations. In addition, Guariento \& Morley (2001) believe that using authentic text is an important way to maintain and increase learners' motivation in language learning (Guariento \& Morley, 2001).

These theories of authenticity are not without criticism. Researchers (Crystal, 1997; Ur, 2008 cited in Baral, 2009) suggest that the idea of authenticity derives from what the native speakers used is blurred because there are more non-native speakers using English than native-ones in diverse contexts, not all utterances by the native speakers are models for language learners; for example, the expression innit cannot be regarded as appropriate use of language, and the language itself is authentic whenever the interlocutors understand each other.

Due to the fact that not all authentic texts suit learners' level and to promote the good sides of this kind of text, it is suggested that EFL teachers in the context of this paper need to be aware of how to choose texts for their language teaching, especially for teaching reading. In order to show how one chooses an appropriate text, the second point of literature review discusses text readability. One definition of readability, according to Wikipedia, is "the ease of reading and understanding a text". The definition of Edgar Dale and Jean Chall (1949), cited in Dubay (2004) towards readability seems to be more concise. They define readability as the easiness of elements in a reading text which the readers could understand and find it interesting. In this paper, readability is understood as the ease of understanding a given text.

The information mentioned above shows that readability can be understood as the ease of understanding a text and it is measured by Flesch (1949). He states that the easiness of text is compatible to its readability score. For that reason, he suggests the equivalent score for the text readability under the name "Flesch reading ease score" (see Apendix 3). Table 1 below briefly illustrates the levels of the readability of a text.

\begin{tabular}{ll}
\hline \multicolumn{1}{c}{ Flesch Reading Ease Score } & \multicolumn{1}{c}{ Style } \\
\hline 90 to 100 & Very easy \\
80 to 90 & Easy \\
70 to 80 & Fairly easy \\
60 to 70 & Standard \\
50 to 60 & Fairly difficult \\
30 to 50 & Difficult \\
0 to 30 & Very difficult \\
\hline
\end{tabular}

Table 1: The analysis of the readability by Flesch

(1949)

It is easy to recognize the simple practicality of the Flesch-Reading-Ease-Score, which is available for use in several word processors. Table 1 shows that a higher "Flesch reading ease score" indicates a text that is easier to read and understand. This paper will apply Flesch's formula to get readability of an authentic text since the researcher wants to emphasize that the teachers should consider readability in their classrooms to decide whether an authentic text is suitable to their learners. It is useful to concentrate on how to understand and possibly enhance the text readability depending on the teacher's goals for the students although no teachers want the text to be easily understood right away.

Besides recognizing the readability of a text, EFL teachers need to know ways to modify or simplify the text in case it is useful in terms of learning, but not suitably readable for their learners' level. Text modification, simplification, and elaboration are among the effective ways suggested by many researchers (Brown, 1985; Tsang, 1987; Yano et al., 1994; and Urano, 2000). The current study will apply the theories of Urano (2000). In his study, Urano uses two strategies to improve learners' comprehension: lexical simplification and elaboration. Lexical simplification is the technique to modify the more complicated words with the simpler ones. Elaboration means the deletion of some unnecessary words for better understanding of a text. Chung (1995) shares Urano's idea of focusing on the effects of elaborative modification 
on second language comprehension. In addition, the studies of Tsang (1987) and Yano et al. (1994) demonstrate that simplified and elaborated texts on foreign language reading comprehension are the two useful ways to make the text readable and help increase the comprehensible level.

In short, the review of literature can be summarized with some key points as follows: authentic text in language classrooms; features of text readability; and some ways to modify text. The following section will mention the methods of conducting this research.

\section{Method of the study}

\section{Participants}

Twenty-six EFL teachers from a community college and a TESOL class in the context of Vietnam were involved in the investigation. The participants are determined as follows:

(1) Fifteen participants at the community college: The most experienced teacher has been teaching for sixteen years and the least experienced has been teaching for two years. While two years is not a long time, the youngest teacher graduated with an excellent degree from a prestigious university in the area and has been recognized as one of the best teachers in the research context.

(2) Eleven participants from the TESOL class: The most experienced participant has been teaching English for twenty-one years and the least experienced has been teaching for three years.

In addition to the teachers mentioned above ten participants from the TESOL class did the pilot questionnaire and test.

\section{Instruments}

All the data used in this research were obtained through the questionnaire and the test

(1) The questionnaire: A questionnaire was first designed with ten items and was divided into two dimensions and it was piloted by ten participants. After getting the data from it, some deletions and modifications were made to create the current questionnaire. Only four items were maintained within two dimensions about the awareness concerning text modification when using authentic texts (two items) and background knowledge in understanding and changing the readability (two items). The final questionnaire aims to measure the perceptions of the participants in terms of using authentic text, their awareness to readability, and their skills in supplementing readability.

(2) The test: The test was designed with an aim to find out whether the participants could really modify the given authentic text or not. The text in this test was downloaded from http:// weblamp.princeton.edu/ pia/main/index. php?option=com_content $\&$ task=blogsectio n\&id=11\&Itemid=39\&limit $=205 \&$ limitstart $=205$. The test requires the participants to suggest the modification in three main streams of lexical use, the complexity of structure, and the organization. A section calling for "other suggestions" was also added to this test. It was also piloted by ten participants.

\section{Procedures}

After piloting the questionnaire and test and making some adjustments, twenty-six copies of questionnaires and tests were delivered directly to twenty- six participants, who returned them within three weeks set by the researcher. In order to help the participants understand the purposes of the questionnaires and the tests, ten minutes was spent explaining the aim of the research and how to complete the questionnaires and the tests. The data obtained from the questionnaires and the tests were processed by SPSS and Microsoft Excel.

The data were collected and analyzed for the changed readability score. The authentic text was modified four times. At first, the modification focused on the lexical simplification. The word "tri-annual" was crossed out and the second word of "adventure" was changed into "trip". In the second time, a suggestion from the website* was applied to improve readability. The two longest sentences were divided into four. Then, similar tasks were applied to other long sentences and the readability score was checked again. Finally, the paragraph was simplified and the sentences were shortened. After each modification, the meaning of the text was carefully compared with the original text to ensure similarity. The word processor of Microsoft Word and the website 
tool to count the Flesch-Reading Ease score were used simultaneously. The reason for using two tools is to ensure the reliability of the changes. To summarize, the data were collected from the modification times of the modified text by normal lexical and structural simplifications.

\section{Results}

The results from the questionnaire and the test show that although the participants do a great job towards text modification, they seem to be unaware of the text readability. The detailed results are shown as follows:

Teachers' attention to readability and modification of authentic texts

Item 1: You pay attention to readability and your students' level when choosing texts for reading lessons.

\begin{tabular}{lllll}
\hline & $\begin{array}{l}\text { Fre- } \\
\text { quency }\end{array}$ & $\begin{array}{l}\text { Per- } \\
\text { cent }\end{array}$ & $\begin{array}{l}\text { Valid } \\
\text { Percent }\end{array}$ & $\begin{array}{l}\text { Cumulative } \\
\text { Percent }\end{array}$ \\
\hline $\begin{array}{l}\text { Valid Neu- } \\
\text { tral }\end{array}$ & 1 & 3.8 & 3.8 & 3.8 \\
$\begin{array}{l}\text { Agree } \\
\text { Strongly }\end{array}$ & 4 & 15.4 & 15.4 & 19.2 \\
Agree & 21 & 80.8 & 80.8 & 100.0 \\
\hline \begin{tabular}{l} 
Total \\
\hline
\end{tabular} & 26 & 100.0 & 100.0 & \\
\hline
\end{tabular}

Table 2: The frequency of the teachers' perception to the readability and students' level

Table 2 showed no percent of disagreement. That means most of the participants agree that they have paid attention to the readability and students' levels when choosing authentic texts (up to $96.2 \%$ ). The rest $3.8 \%$ is reserved for neutral idea.

Item 2: You focus on the vocabulary and structures in modifying the texts.

\begin{tabular}{lllll}
\hline & $\begin{array}{l}\text { Fre- } \\
\text { quency }\end{array}$ & $\begin{array}{l}\text { Per- } \\
\text { cent }\end{array}$ & $\begin{array}{l}\text { Valid } \\
\text { Percent }\end{array}$ & $\begin{array}{l}\text { Cumulative } \\
\text { Percent }\end{array}$ \\
\hline $\begin{array}{l}\text { Valid Dis- } \\
\text { agree }\end{array}$ & 2 & 7.7 & 7.7 & 7.7 \\
Neutral & 3 & 11.5 & 11.5 & 19.2 \\
$\begin{array}{l}\text { Agree } \\
\text { Strongly }\end{array}$ & 74 & 53.8 & 53.8 & 73.1 \\
Agree & & 26.9 & 26.9 & 100.0 \\
\hline Total & 26 & 100.0 & 100.0 & \\
\hline
\end{tabular}

Table 3: The frequency of the teachers' perception about the ways to modify texts
This second item aims to double-check in more detail on how the text is modified and the correlation between it and the first item of teacher's attention to readability and their students' level. The results showed that a large number of participants (80.7\%) agreed that modifying the texts by focusing on vocabulary and structures was most effective. This agreement could indicate that teachers have some understanding of text modification, whether or not they have been made aware of the practice. This result could be explained that the teachers' ability may come from their experiences without noticing.

Item 3: Knowing how to figure out or to get the text readability (by using formula, computer programmes...)

\begin{tabular}{lllll}
\hline & $\begin{array}{l}\text { Fre- } \\
\text { quency }\end{array}$ & $\begin{array}{l}\text { Per- } \\
\text { cent }\end{array}$ & $\begin{array}{l}\text { Valid } \\
\text { Percent }\end{array}$ & $\begin{array}{l}\text { Cumulative } \\
\text { Percent }\end{array}$ \\
\hline $\begin{array}{l}\text { Valid Dis- } \\
\text { agree }\end{array}$ & 3 & 11.5 & 11.5 & 11.5 \\
$\begin{array}{l}\text { Disagree } \\
\text { Neutral }\end{array}$ & 2 & 7.7 & 7.7 & 19.2 \\
Agree & 9 & 26.9 & 26.9 & 46.2 \\
$\begin{array}{l}\text { Strongly } \\
\text { Agree }\end{array}$ & 5 & 34.6 & 34.6 & 80.8 \\
\hline Total & 26 & 10.2 & 19.2 & 100.0 \\
\hline
\end{tabular}

Table 4: The frequency of the teachers' beliefs about their ability to figure out the readability

This item belongs to the second dimension of background knowledge in understanding and changing the readability. The question was posed with the purpose of checking whether there is any connection between the teachers' knowledge of how to assess readability and their perceptions of readability as an educational tool. It is surprising that very little correlation has occurred. Compared to 96.2 percent teachers' awareness on readability, only 53.8 percent participants stated that they knew how to assess readability by using a computer tool or counting by hand. It means that 46.2 percent participants did not know the ways to assess the readability of texts. The findings show that someone with awareness of readability can modify a text to enhance its readability, but may not know the ways to calculate readability. That means some teachers without knowing the concept of readability could judge the texts with their experience and make modifications as proven in 
the results where all participants suggested good ways to modify the given text.

Item 4: the formula to get the text readability of Flesch-Kincaid Reading Ease Score

\begin{tabular}{lllll}
\hline & $\begin{array}{l}\text { Fre- } \\
\text { quency }\end{array}$ & $\begin{array}{l}\text { Per- } \\
\text { cent }\end{array}$ & $\begin{array}{l}\text { Valid } \\
\text { Percent }\end{array}$ & $\begin{array}{l}\text { Cumulative } \\
\text { Percent }\end{array}$ \\
\hline $\begin{array}{l}\text { Valid Dis- } \\
\text { agree }\end{array}$ & 3 & 11.5 & 11.5 & 11.5 \\
Disagree & 1 & 3.8 & 3.8 & 15.4 \\
Neutral & 13 & 50.0 & 50.0 & 65.4 \\
Agree & 7 & 26.9 & 26.9 & 92.3 \\
Strongly & 2 & 7.7 & 7.7 & 100.0 \\
Agree & & & & \\
\hline Total & 26 & 100.0 & 100.0 & \\
\hline
\end{tabular}

Table 5: The frequency of the teachers' knowledge about the formula to get readability

This item aims to check the reliability of the third item. The teachers who are aware of readability may know the formula for finding readability. There is a widely used formula to get the text readability. However, it is quite surprising that only 35.4 percent of the participants agree that they know the formula. 50 percent of them have no idea, and they opted for the 'neutral' option. That means while teachers care about readability in choosing texts for reading lessons, they may not actually check it. In other words, the teachers may have awareness of readability and be able to modify a text without knowing the exact readability score of a chosen text.

In short, it is great to notice that almost all teachers are aware of the text readability for reading lessons when they adapt them from the authentic sources. However, the findings indicated that there is just a little correlation between the teachers' perception about text readability and their knowledge about the theory behind text readability. The answer to the research question about teachers' perceptions about readability and modification of authentic texts chosen for teaching reading is that knowledge of readability theory is not necessary for effective text modification.

The impact of the modifications on text readability

After mentioning the results of the questionnaire, the collected data from the test were processed by MS Word and the website tool to count the Flesch-
Reading Score. Figure 1 illustrated the results as follows:

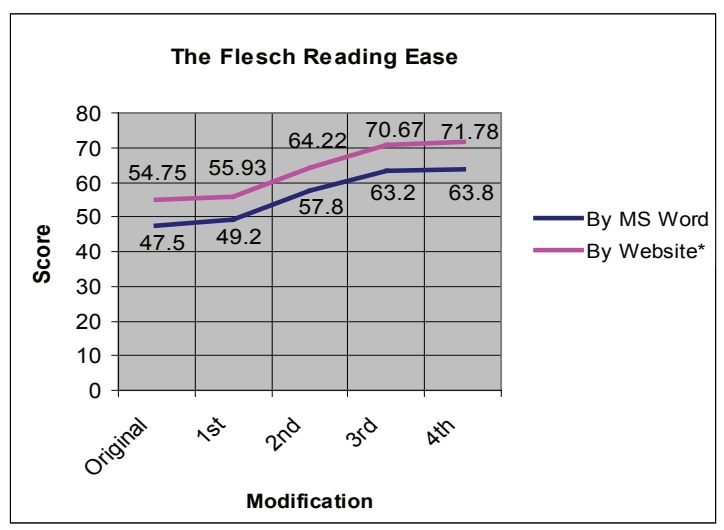

Figure 1: The impact of modifications on the readability score *http://www.online-utility.org/english/readability_test_and_improve.jsp

This figure shows that the Flesch-Reading Ease score increases after the text was modified in all four modifications. That means the modification of the authentic text positively changed its readability score. Of course, the second coefficient that goes with readability is the decreased Flesch-Kincaid Grade level. Actually, it is easy to recognize the changes. The modifications enhance the text readability. About seventeen percent of the increased score adjusted the level of text from 'fairly difficult' to 'fairly easy'.

\section{Application in teaching}

In the context of this paper, students are not good at reading comprehension and always complain that the texts are too difficult for them to understand. The issue may come from the mismatches among the students' reading levels and the ease of text. Due to that situation, teachers are suggested to choose appropriate texts for teaching reading or they need to be aware of readability and modification towards reading materials is important. In other words, teachers should pay more attention to text readability when using authentic texts because of students' comprehension. In fact, this research demonstrated that the participants' modifications worked well in enhancing the readability score despite knowing how to get it or not. That ensures the insights of the ability to modify and use authentic texts. In short, it is never useless to check readability and do some modification before 
adapting such materials in reading lessons. One who does that shows their right attitude and good preparation for teaching. This kind of awareness helps not only the teachers, but also students with the ease of reading comprehension.

Dealing with the application of the findings in the research context, the teachers can apply the suggestions for readability improvement (see Appendix 3), know when to do modification, and decide when the authentic texts are ready for use. It is possible to simplify sentence structures; shorten long sentences; and choose the replacements for the low frequency words. That is also a chance for the teachers to re-read their chosen texts before adapting to the real lessons. Moreover, the results of the current research reveal that teachers familiar with the Internet and MS Word processing tools can find it easy to check and adapt readability. That means the reading lessons with the adaptation of authentic texts in the future could best suit students' ability. The modified texts at students' level specify the teachers' jobdevotion. That will enhance students' interests and motivations in studying this subject. Again, the reading lessons will bring to the class more than just the knowledge, but the improved text can keep the class interesting for the teacher and students.

In summary, the advanced feature of authentic texts recognized as providing real language for the real communicative situations as mentioned earlier in this paper should be noticed, but should be along with its readability levels. The teachers should be encouraged when they have carefully checked the text readability and modified texts before adapting to reading lessons. That would help the students for their language acquisition and ability to master English. The right perceptions of the teachers about readability and modification when using authentic texts would bring many advantages to the lessons and the students as well. The students will acquire the language easier with the appropriate input.

\section{Conclusion}

The role of authentic text is significant in helping learners acquire the foreign language naturally. However; as mentioned above, learners also face some constraints dealing with an authentic text such as being not suitable for their ability, or having unfamiliar words. For that reason, the teachers should be aware of the importance of text readability and modification to solve the mentioned problems. In fact, the readability itself means nothing to the students, but the teachers can use it to modify the authentic texts, which are suitable to students' level of understanding. In fact, many teachers want to modify texts, but some of them do not care yet about text readability and others do not want to change their teaching habits and materials. That may hold back some language learners because out-dated materials do not always meet the current requirements of the moving world.

Nguyen Duy Khang is especially interested in teaching $\mathrm{EFL}$, sharing ideas and doing research for professional development in a community college near the Gulf of Thailand. His family and friends have encouraged those interests. That encouragement drove him to his MA degree in 2009 and he has accomplished plenty of research in his college since 2002.

\section{References}

Baral, L. N. (2009). An Investigation of Authenticity in a Nepalese Secondary ESL Textbook and its Supplementation. Journal of NELTA Vol. 14 No. 1-2 .

Brown, R. L. (1985). A comparison of the comprehensibility of modified and unmodified ESL reading materials. Unpublished Master's thesis, University of Hawai'i at Manoa, Honolulu.

Chung, H. (1995). Effects of elaborative modification on second language reading comprehension and incidental vocabulary learning. Unpublished master's thesis, University of Hawai'i at Manoa, Honolulu.

Crystal, D. (1997). English as a global language. Cambridge: CUP.

DuBay, H. W. (2004). The principles of readability. Retrieved on February 4, 2008 from www.nald. ca/fulltext/readab/readab.pdf

Flesch, R. (1949). The art of readable writing. New York: Harper.

Guariento, W. \& Morley, J. (2001). Text and task authenticity in the EFL classroom. ELT Journal 55.4, 347-353. 
Kitao, K. \& Tanaka, S. (2007). Authorized Junior High School English Textbooks in Japan: From the Viewpoint of Vocabulary and Readability. Retrieved from http://glocall.org/course/ view.php?id=20.

Little, D., Devitt, S., \& Singleton, D. (1988). Authentic texts in foreign language teaching: Theory and Practice. Dublin: Authentik.

Tsang, W. K. (1987). Text modification in ESL reading comprehension. Unpublished Scholarly Paper, University of Hawai'i at Manoa, Honolulu.

Urano, K. (2000). Lexical simplification and elaboration: sentence comprehension and incidental vocabulary acquisition. Retrieved on Jan 18, 2008 from http://www.urano-ken. com/research/thesis.pdf

Ur, P. (2008). The fully competent speaker of English as a lingua franca. A paper presented at IATEFL Conference, Exeter April 8, 2008.

Yano, Y., Long, M., H., \& Ross, S. (1994). The effects of simplified and elaborated texts on foreign language reading comprehension. Language Learning, 44, 189-219.

Wilkins, D. (1976). Notional syllabuses. Oxford: Oxford University Press.

\section{APPENDIX 1}

\section{The Questionnaire}

Please put a tick or a cross in the column that you choose for each statement.

\begin{tabular}{|c|c|c|c|c|c|}
\hline \multirow[b]{2}{*}{ Questions } & \multicolumn{5}{|c|}{ Scales of agreement } \\
\hline & $\begin{array}{l}\text { Strongly } \\
\text { Disagree }\end{array}$ & Disagree & Neutral & Agree & $\begin{array}{l}\text { Strongly } \\
\text { Agree }\end{array}$ \\
\hline \multicolumn{6}{|c|}{ A. The awareness to the text readability and modification when using authentic texts for teaching reading } \\
\hline \multicolumn{6}{|l|}{$\begin{array}{l}\text { 1. You pay attention to the readability and } \\
\text { level or grade of your students when choos- } \\
\text { ing texts for reading lessons }\end{array}$} \\
\hline \multicolumn{6}{|l|}{$\begin{array}{l}\text { 2. You focus on the vocabulary and structures } \\
\text { in modifying the texts. }\end{array}$} \\
\hline \multicolumn{6}{|l|}{ B. Background about the readability of texts } \\
\hline \multicolumn{6}{|l|}{$\begin{array}{l}\text { 3. You know how to figure out or get the } \\
\text { readability of texts. (By using a formula, a } \\
\text { computer programme...) }\end{array}$} \\
\hline $\begin{array}{l}\text { 4. The formula to get the text readability of } \\
\text { Flesch }- \text { Kincaid Reading Ease }=206.835- \\
\text { ( } 1.015 \times \text { (total number of words / total num- } \\
\text { ber of sentences)) }-(84.6 \times \text { (total number of } \\
\text { syllables / total number of words)) }\end{array}$ & & & & & \\
\hline
\end{tabular}

Code: 


\section{Appendix 2}

\section{The Test}

Please read the text and suggest the modifications for the level of upper beginners of English! The following text is an authentic text written by native speakers of English. Its genre is narration.

In the fall, Laura came to Vietnam straight from Alaska, a barely inhabited land of mountains and snow, to an over inhabited land of rice fields, heat, and motorbikes. Laura has found her place and impressed locals by biking over 100 kilometers to Ha Tien, a coastal beach town, and to Oc Eo, the site of an ancient Indian Civilization (all on her shockingly reliable Chinese single gear). Adventures aside, the real highlights have come through unexpected interactions with the warm people of Rach Gia. One weekend, her student took her far out to the countryside, a place only accessible by boat, to visit the student's grandmother. Another student invited her to lend a hand in the fields during one of the triannual harvests. Her most recent adventure was in the studio though recording her voice for Vietnam Airlines. "Ladies and Gentlemen, all passengers on flight VN 482 to Phu Quoc and Ho Chi Minh City, please board". So, listen up next time you visit the Rach Gia airport and please, make sure to turn off all electronic devices.

Modifications in terms of vocabulary, please specify: (change the words; add more definition to difficult or strange words; delete some unnecessary words; and so on)

Modifications in terms of structural complexity, please specify:

In terms of paragraph organization, please specify:

Other suggestions, please specify: 


\section{Appendix 3}

\section{The way to get readability}

A. How to display readability score in Microsoft Word

- $\quad$ On the Tools menu, click Options, and then click the Spelling \& Grammar tab.

- Select the Check grammar with spelling check box.

- $\quad$ Select the Show readability statistics check box, and then click $\boldsymbol{O K}$.

- Click Spelling and Grammar on the Standard toolbar. $(\stackrel{A B C}{)})$ or F7

The readability score will display after the checking accomplishes.

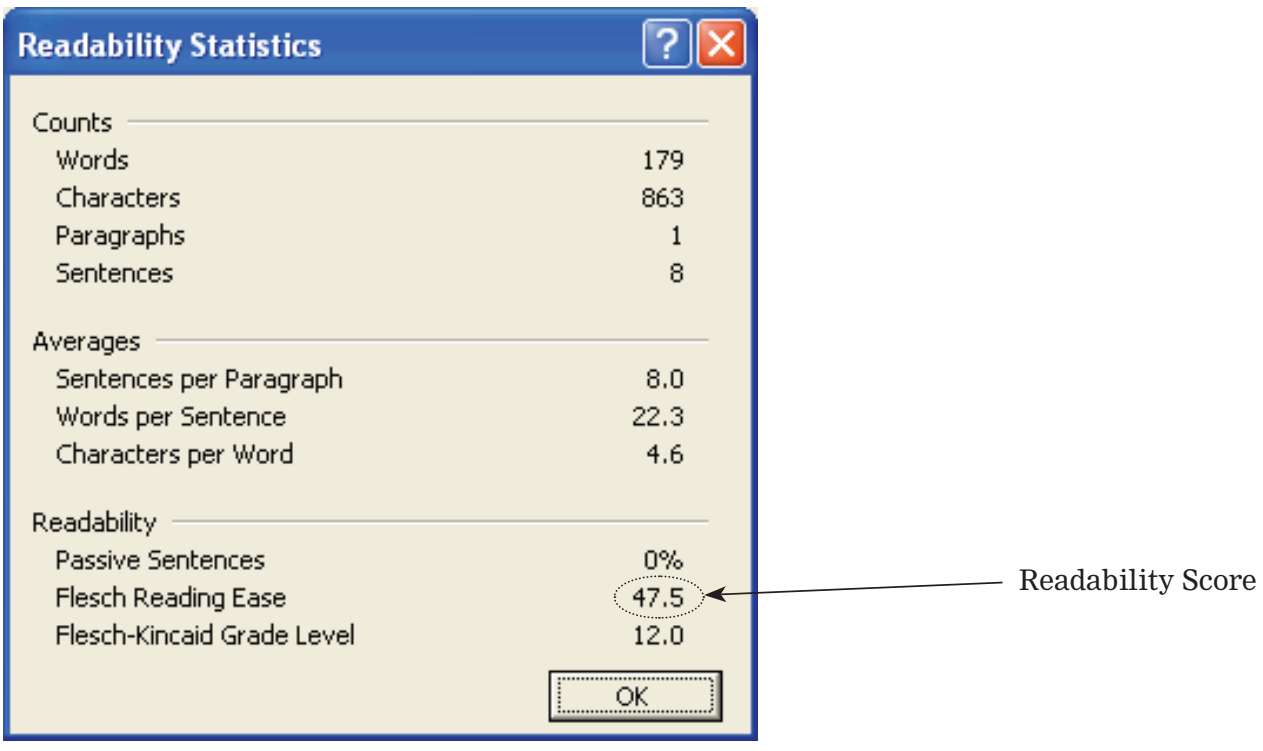

B. Using website tool to get readability

- Type http://www.online-utility.org/english/readability_test_and_improve.jsp into the address line of your internet explorer.

- Copy the texts and paste in the area for text or type the te texts here.

- $\quad$ Click on Process Text.

The website will display much information about the text with many kinds of measurements for readability. In addition, it suggests the considerations to improve the text readability. 